\title{
Chaetophractus vellerosus (Mammalia: Dasypodidae) in the Ensenadan (Early - Middle Pleistocene) of the southeastern Pampean region (Argentina). Paleozoogeographical and paleoclimatic aspects
}

\author{
Esteban Soibelzon, Alfredo Armando Carlini, Eduardo Pedro \\ Tonni and Leopoldo Héctor Soibelzon, La Plata \\ With 4 figures
}

Soibelzon, E.,CARlini, A.A., Tonni, E. P. \& Solbelzon, L. H. (2006): Chaetophractus vellerosus (Mammalia: Dasypodidae) in the Ensenadan (Early - Middle Pleistocene) of the southeastern Pampean region (Argentina). Paleozoogeographical and paleoclimatic aspects. - N. Jb. Geol. Paläont. Mh., 2006: 734-748; Stuttgart.

\begin{abstract}
The xenarthran fauna recognized for the Ensenadan age is particularly abundant; Dasypodidae comprise approximately $20 \%$ of this fauna. Chaetophractus vellerosus is recorded in the Pampean region from the Bonaerian-Lujanian (Middle Pleistocene - Late Pleistocene/Early Holocene) to the present, with a current disjunct distribution (a continuous main area comprising the Gran Chaco and central Argentina, and a secondary area in the coastal region of Buenos Aires Province) attributed to a wider paleodistribution. The materials presented here are from Ensenadan sediments outcropping at Punta Hermengo (General Alvarado County, Buenos Aires Province), that would have been deposited under arid to semiarid climate conditions. These allow extension of the temporal distribution of the species to the Ensenadan in the Pampean region, as well as representing new evidence to test hypotheses of distributional changes related to global climatic variations recognized for the Quaternary. In this sense, the current disjunct distribution can be interpreted as the result of fundamentally humid recent conditions that resulted in a relict occurrence of the species in coastal areas.
\end{abstract}

Zusammenfassung: Die Xenarthriden-Fauna aus dem Ensenandense (UnterPleistozän) ist sehr divers, davon machen die Dasypodidae etwa $20 \%$ der gesamten Artenzahl aus. Chaetophractus vellerosus kommt im Pampa-Gebiet vor, vom 
Bonaerense (Mittel-Pleistozän) bis rezent, mit einer heutzutage disjunkten geographischen Verbreitung und einer weiteren Verbreitung in der erdgeschichtlichen Vergangenheit. Die hier beschriebenen Funde stammen von Punta Hermengo (General Alvarado County, Bundesstaat Buenos Aires), aus Schichten des Ensenandense, die in einer trockenen Umwelt abgelagert wurden. Die Fossilien belegen eine größere zeitliche Verbreitung dieser Art im Pampa-Gebiet (Unter-Pleistozän). Die heutige disjunkte Verbreitung von $C$. vellerosus korreliert mit einer klimatischen Änderung (höhere Feuchtigkeit), wodurch die Verbreitung auf trockene Gebiete eingeschränkt wurde.

\section{Introduction}

Xenarthrans are particulary abundant among the middle- to large-sized mammals recorded in the Ensenadan (Early - Middle Pleistocene). Within this group, the family Dasypodidae, represented by 8 genera and 20 species or 21 in the living mammalian fauna (WETZEL 1982; NoWAK 1999 and others), comprise $20 \%$ of the total Ensenadan xenarthrans, with 5 genera and at least 7 recognized species (CARLini \& SCILlato-Yané 1999). Among the Euphractinae Euphractini, Chaetophractus villosus is recorded from the Chapadmalalan (Pliocene) and C. vellerosus, from the Bonaerian-Lujanian (Middle Pleistocene - Late Pleistocene-Early Holocene) to the present (Scillato-Yané 1982; Carlini \& Vizcaíno 1987; Carlini \& ScillatoYANÉ 1999).

The current distribution of $C$. vellerosus is disjunct, with a main continuous area extending over the Gran Chaco and central Argentina, and a secondary area in central latitudes of the coastal region in Buenos Aires Province (CARlini \& VizCAíno 1987) (Fig. 1). CARLINI \& Vizcaíno have explained this disjunct distribution as a relict of a more widespread distribution that comprised a larger part of the territory currently included in Buenos Aires province, during the Late Pleistocene and part of the Holocene.

The local edaphic characteristics in the coastal region of the Buenos Aires Province (Bahía Samborombón), determine more xeric conditions respect to the regional soils ones (MURRIELLO et al. 1993). The local soils are covered by xerophytic trees known collectively as "Talares" (Celtis tala xeric forests). These "Talares" develop on elevated shell-beds ("albardones"), covered by markedly sandy soils; the ensemble forms a system that is extremely permeable to water. These deposits/beds originated during Holocene marine 


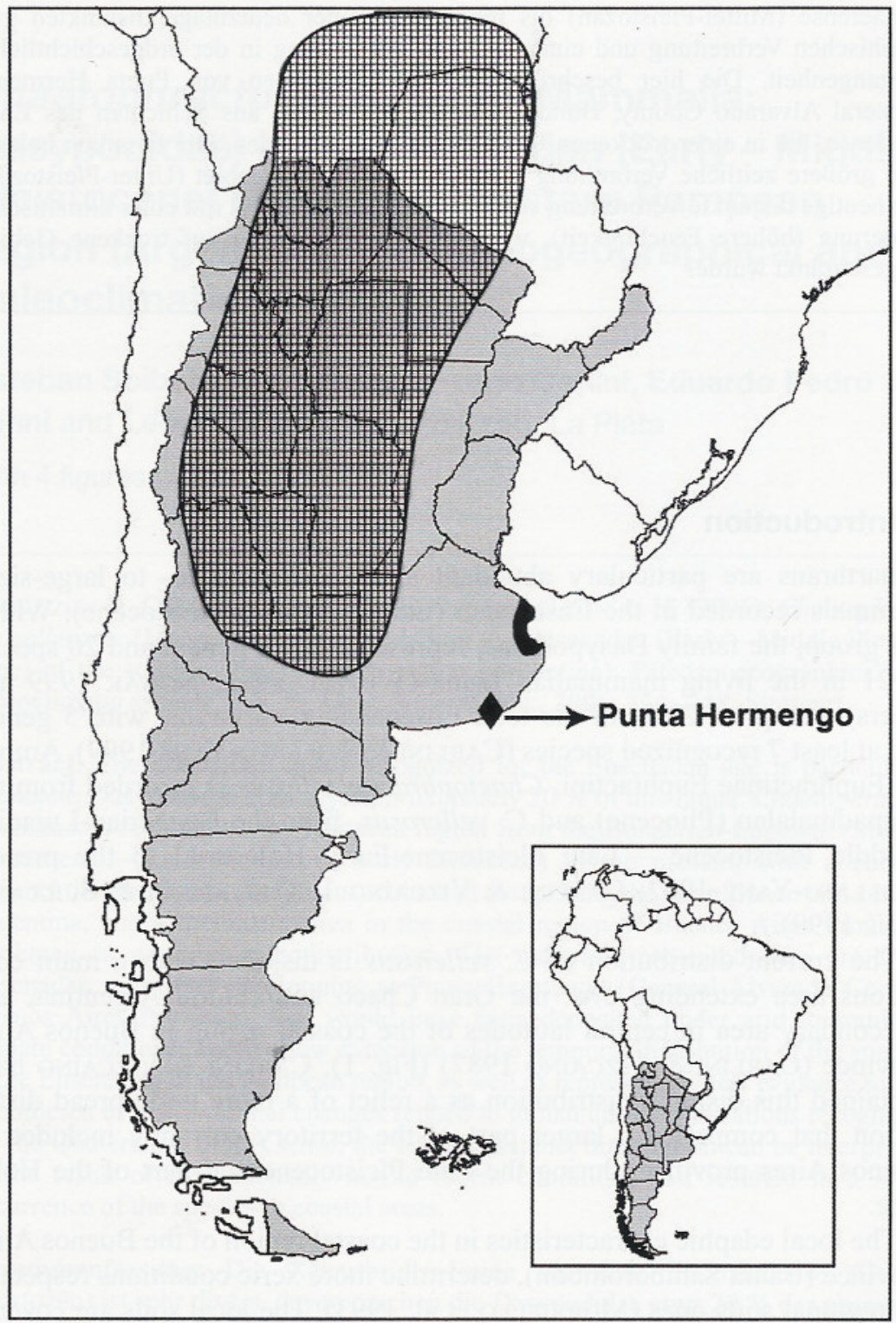

Fig. 1 (Legend see p. 737) 


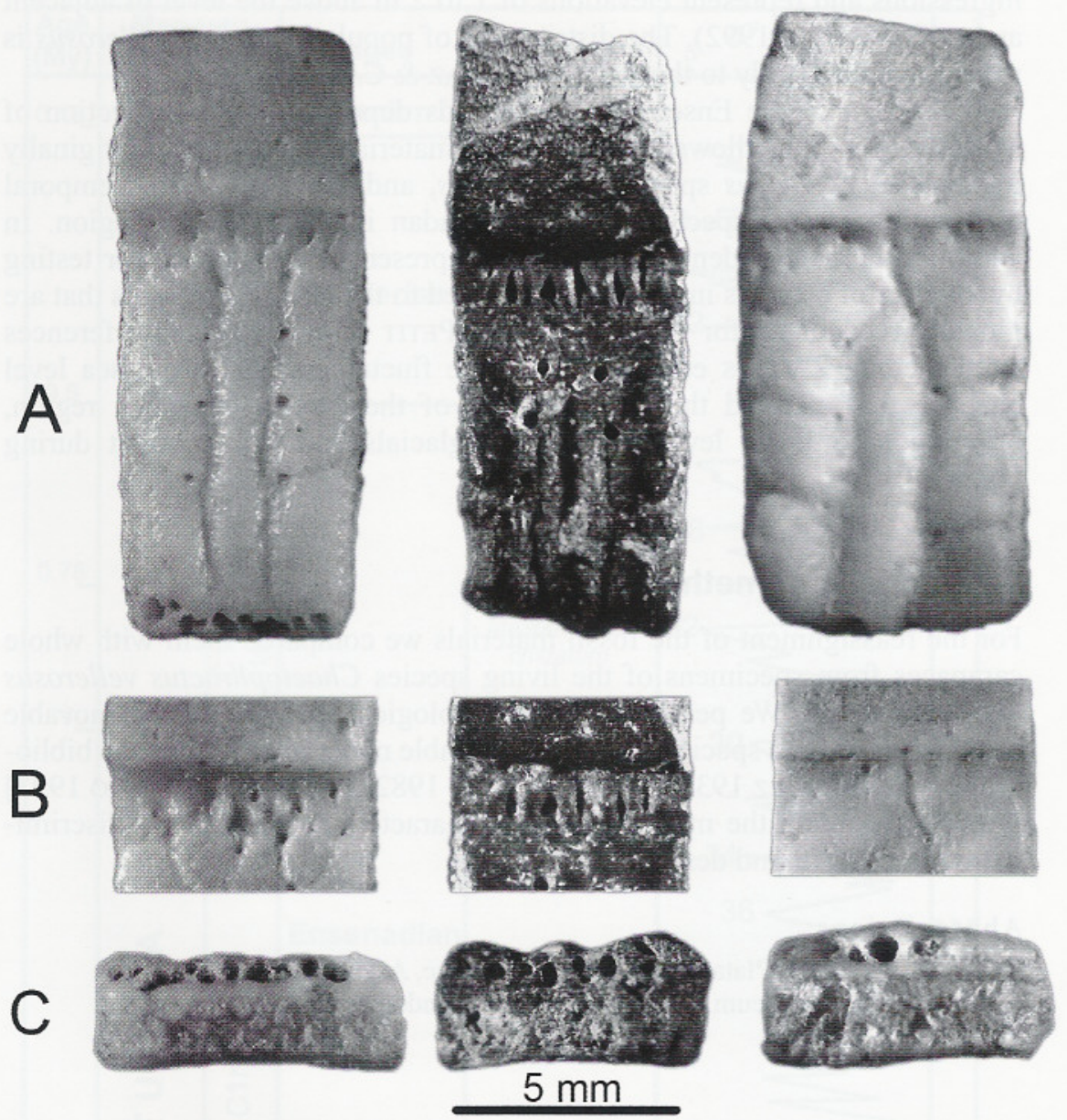

Fig. 2. A - Dorsal view of movable osteoderms of: Chaetophractus vellerosus; $\uparrow C$. vellerosus (MLP, 94-I-1-22) and Zaedyus pichiy; B - Detail of area between articulation zone and posterior zone of the osteoderm; C - Posterior view of the osteoderms and location of the piliferous foramina.

Fig. 1. Approximated current distribution of $C$. vellerosus, in squared the main area and in black the relictual area in Buenos Aires. Black diamond shows the provenance of fossil remains. 
ingressions and represent elevations of 1 to $2 \mathrm{~m}$ above the level of adjacent areas (GoyA et al. 1992). The distribution of populations of C. vellerosus is restricted specifically to these sectors (GLAZ \& CARLINI 1999).

A revision of the Ensenadan dasypodids deposited in the collection of Museo de La Plata allowed us to reassign materials that had been originally identified as Zaedyus sp. to C. vellerosus, and thus extend the temporal distribution of this species to the Ensenadan in the Pampean region. In addition, the newly identified materials represent new evidence for testing hypotheses of changes in distribution related to the climatic changes that are globally recognized for the Quaternary (PETIT et al. 1999 and references cited therein; ZACHOS et al. 2001). These fluctuations produced sea level changes that affected the continentality of the current Pampean region, bringing it to lower levels during interglacials and increasing it during glacials.

\section{Material and methods}

For the reassignment of the fossil materials we compared them with whole carapaces from specimens of the living species Chaetophractus vellerosus and Zaedyus sp. We performed a morphological analysis of the movable osteoderms of both species (using the available materials and specific bibliography [FERNÁNDEZ 1931; SCILlATO-YANÉ 1982; VizCAÍNO \& BARGO 1993] in order to obtain the more significant characters for taxonomic discrimination (see Fig. 2 and descriptions below).

Abbreviations:

MLP: Museo de La Plata, Buenos Aires province, Argentina.

BMNH: British Museum of Natural History, London.

Fig. 3. Chronostratigraphic time scale for the Quaternary of the Pampean region according to CIONE \& TONNI (1999), $\delta^{18} \mathrm{O}$ curve for benthic forams, modified from SHACKLETON (1995), G: Patagonian glaciation, from RABASSA et al. (2005). 


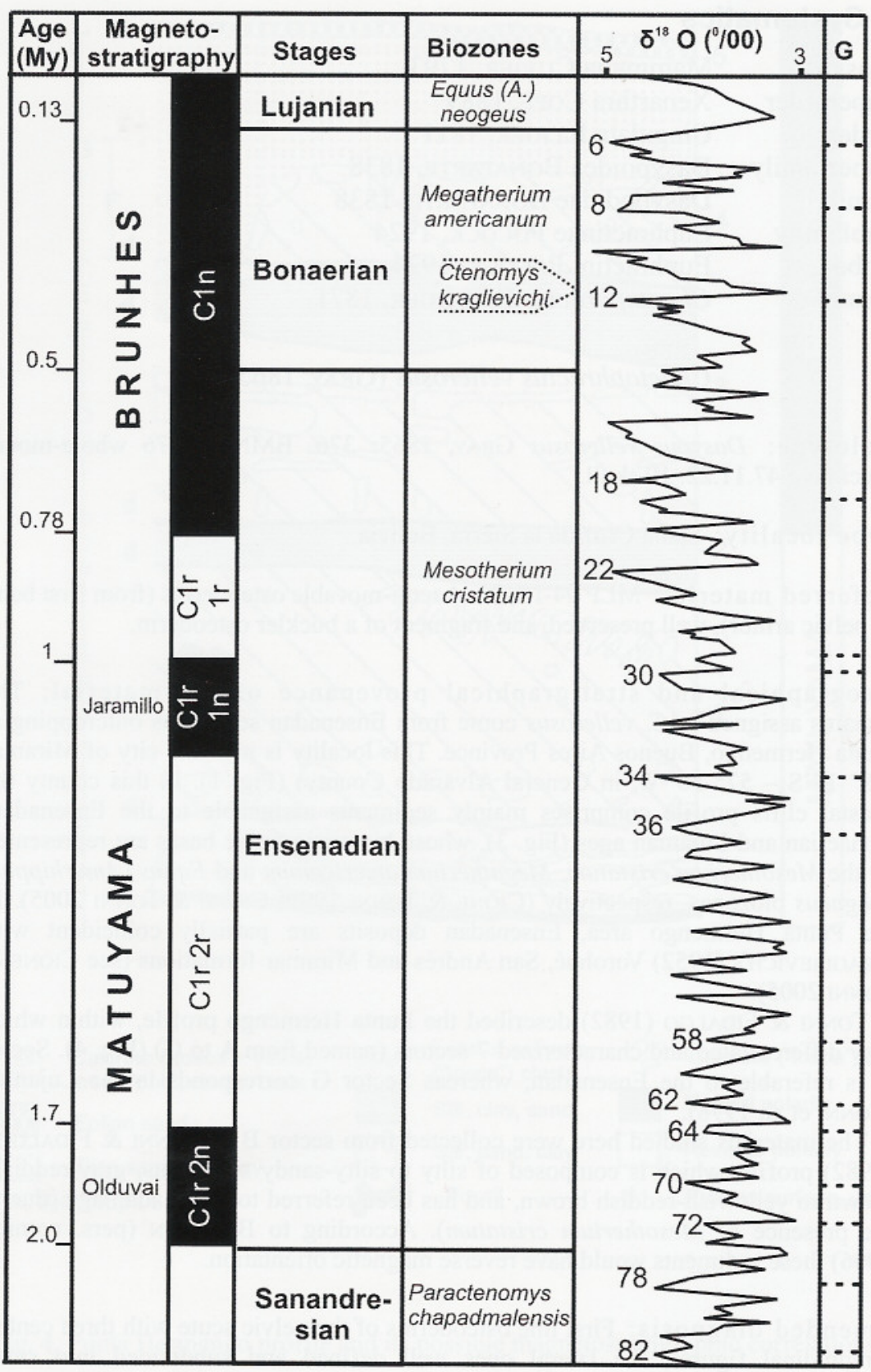

Fig. 3 (Legend see p. 738) 


\section{Systematics}

$\begin{array}{ll}\text { Class } & \text { Mammalia CUVIER, 1793 } \\ \text { Superorder } & \text { Xenarthra COPE, 1889 } \\ \text { Order } & \text { Cingulata ILlIGER, 1811 } \\ \text { Superfamily } & \text { Dasypoidea BONAPARTE, 1838 } \\ \text { Family } & \text { Dasypodidae BONAPARTE, 1838 } \\ \text { Subfamily } & \text { Euphractinae POCOCK, 1924 } \\ \text { Tribe } & \text { Euphractini POCOCK, 1924 } \\ \text { Genus } & \text { Chaetophractus FITZINGER, 1871 }\end{array}$

Chaetophractus vellerosus (GRAY, 1865)

Holotype: Dasypus vellerosus GraY, 1865: 376. BMNH 1376 whole-mount specimen; 47.11.22. 10 skull.

Type locality: Santa Cruz de la Sierra, Bolivia.

Referred material: MLP 94-I-1-22: 4 semi-movable osteoderms (from first band of pelvic armor), well preserved, and fragment of a buckler osteoderm.

Geographical and stratigraphical provenance of the material: The remains assigned to $C$. vellerosus come from Ensenadan sediments outcropping at Punta Hermengo, Buenos Aires Province. This locality is near the city of Miramar $\left(38^{\circ} 17^{\prime} \mathrm{S}-57^{\circ} 50^{\prime} \mathrm{W}\right.$, in General Alvarado County) (Fig. 1). In this county the coastal cliffs profile comprises mainly sediments assignable to the Ensenadan, Bonaerian and Lujanian ages (Fig. 3), whose biostratigraphic bases are represented by the Mesotherium cristatum, Megatherium americanum and Equus (Amerhippus) neogaeus biozones, respectively (CIONE \& TONNI 1999; CIONE \& TONNI 2005). In the Punta Hermengo area, Ensenadan deposits are partially coincident with KRAGLIeVICH's (1952) Vorohué, San Andrés and Miramar formations (see Cione \& TONNI 2005).

TonNI \& Fidalgo (1982) described the Punta Hermengo profile, within which they differentiated and characterized 7 sectors (named from A to G) (Fig. 4). Sector A is referable to the Ensenadan, whereas Sector G corresponds to the Lujanian (TonNI et al. 1998).

The materials studied here were collected from sector B of TonNI \& FIDalgo's (1982) profile, which is composed of silty to silty-sandy sediments, gray-reddishbrown to yellowish-reddish brown, and has been referred to Ensenadan age (due to the presence of Mesotherium cristatum). According to BIDEGAIN (pers. comm., 2006) these sediments would have reverse magnetic orientation.

Emended diagnosis: First line osteoderms of the pelvic scute with three central longitudinal figures, the lateral ones well defined and subdivided into small 


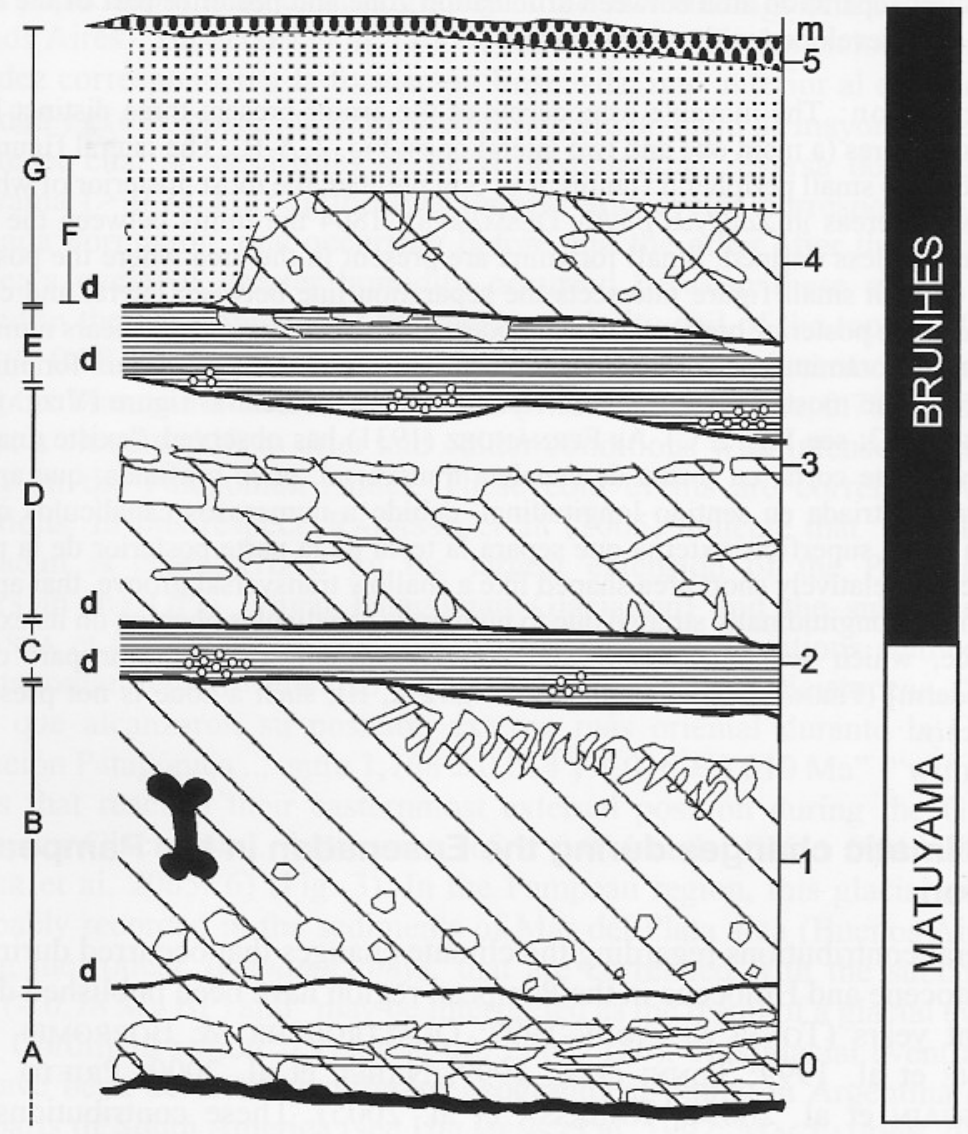

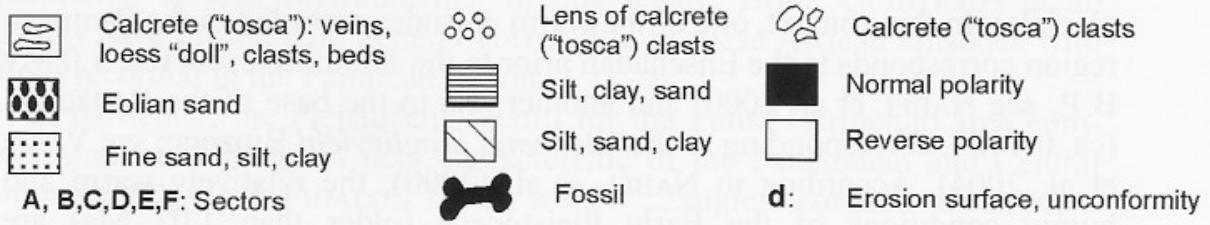

Fig. 4. Punta Hermengo profile and its possible magnetostratigraphic correlations. 
tubercles; separation area between articulation zone and posterior part of the osteoderm well developed with rugose surface.

Description: The movable osteoderms of the armor present three distinct longitudinal figures (a main one and two lateral ones; Fig. 2. A-B). The lateral figures are divided into small peripheral figures, 4 or 5 in number, the most posterior of which is largest, whereas in Zaedyus pichiy DESMAREST, 1804 the limits between the small figures are less defined. Small foramina are present in the area where the posterior apex of each small figure intersects the separation line between lateral and central figures. The posterior border of the osteoderms is rather straight and bears numerous piliferous foramina, whereas it is very thin and has scarce piliferous foramina in Z. pichiy; the most evident foramen coincides with the central figure (VIZCAíno \& BARGo 1993; see Fig. 2. C). As FernÁNDEZ (1931) has observed, "existe una zona relativamente corta, en forma de canaleta transversal, poco profunda, que aparece áspera y estriada en sentido longitudinal, debido a numerosos canalículos que se abren en su superficie externa que separa la tecla de la parte posterior de la placa" [there is a relatively short area shaped like a shallow transversal groove, that appears rough and longitudinally striated due to numerous canalicules opening on its external surface, which separates the articulation zone from the posterior part of the osteoderm] (FERNÁNDEZ 1931: 64; see Fig. 2 A, B); such a zone is not present in Z. pichiy.

\section{Climatic changes during the Ensenadan in the Pampean region}

Several contributions regarding the climate changes that occurred during the Pleistocene and Holocene in the Pampean region have been published during recent years (TONNI \& CiONE 1997; QuATTROCCHIO \& BORROMEI 1998; Cione et al. 1999; Tonni et al. 1999, Nabel et al. 2000; Prieto 2000; BIDEGAIN et al. 2005 b; RABAssa et al. 2005). These contributions emphasize the predominance of more arid than present conditions during the Pleistocene, along with the detection of punctual faunal episodes corresponding to conditions as warm as or warmer than the current ones (interglacials). In this context, one of the warm episodes recorded in the Pampean region corresponds to the Ensenadan prior to the Jaramillo event (ca. 1.0 My B.P., see NABEL et al. 2000) and another one to the base of the Bonaerian (ca. 0.4 Ma, corresponding to the Ctenomys kraglievichi Biozone; see VERzI et al. 2004). According to NABEL et al. (2000), the relatively warm and humid conditions of the Early Pleistocene (older than $1.07 \mathrm{Ma}$ ) are evidenced by both faunal remains (Tapiridae, Procyonidae and Echimyidae) and lithology. 
In a paper about magnetostratigraphy in the surroundings of La Plata city (Buenos Aires), BIDEGAIN et al. (2005c) stated that "los dos ciclos mayores de aridez corresponden a la formación Ensenada, uno anterior al cambio de polaridad y el otro posterior, entre ambos ocurrió un ciclo de mayor humedad durante el cual se desarrolló el suelo de polaridad reversa del tope de Matuyama ( $>0.78 \mathrm{Ma}$ )" ["the two longest arid cycles correspond to the Ensenada Formation, one occurring before and the other after the polarity change; a cycle of greater humidity occurred between these cycles and resulted in the development of the reverse polarity soil of the top of Matuyama (>0.78 My)"] (BIDEGAIN et al. 2005c: 7). The sediments deposited during the Matuyama-Bruhnes transition (Middle Pleistocene, 0.78 My B.P.) suggest a climate shift to drier and colder conditions with intense volcanic activity in the Patagonian Andes. These cold events are correlated with glaciations. In this respect, RABASSA et al. (2005) indicate that "The Late Ensenadan is characterized by the largest extension of the Patagonian glaciers in the GPG [Great Patagonian Glaciation] and the subsequent" (RABASSA et al. 2005: 99). It is noteworthy that the glaciations studied in the Patagonian region were also frequent during the early Pleistocene, "con hielos que alcanzaron su posición externa más oriental durante la Gran Glaciación Patagónica ... entre 1,168 $\pm 0,014$ y 1,016 $\pm 0,010$ Ma" ["with ice masses that reached their easternmost external position during the Great Patagonian Glaciation ... between $1.168 \pm 0.014$ and $1.016 \pm 0.010 \mathrm{My}$ "] (SINGER et al. 2005: 6) (Fig. 3). In the Pampean region, this glacial event is probably recorded in the sediments of Mar del Plata area (Buenos Aires) bearing the rodent Tympanoctomys, that are correlated with the subchron $\mathrm{C} 1 \mathrm{r} 1 \mathrm{r}(>0.78 \mathrm{My} \mathrm{BP})$ and "may be interpreted as the result of a glacial event on the Cordillera region" (VerzI et al., 2002: 156). This glacial event also may have been detected at different geographical points in Argentina and other parts of South America (see HeLmens et al. 1997; MACFADDEN 2000; Singer et al. 2004). Likewise, DeMENOCAL (2004) recorded taxonomic changes in African bovids between 1.8 and 1.2 My B.P, tending to a greater adaptation to arid environments. In this regard, BOBE QuINTEROs et al. (2004) have presented a general correlation of these African episodes with those recorded in the Pampean region.

In particular, the Pleistocene record for the Punta Hermengo area comprises an assemblage of taxa characteristic of the Patagonian and Central Domains (TONNI \& FIDALGO 1982); which “... sugiere condiciones ambientales de menor temperatura y humedad que las registradas actualmente en el área de estudio" [suggests environmental conditions with lower temperature and humidity than those currently recorded in the study area"] (ToNNI et al. 1998: 78). 


\section{Results and discussion}

\subsection{Chronological aspects}

The preliminary magnetostratigraphic studies performed by BIDEGAIN (pers. comm., 2006) at Punta Hermengo yielded reverse magnetic orientation for the sediments bearing the Chaetophractus remains. The native ungulate, Mesotherium cristatum, has only been recorded in the $\mathrm{C} 1 \mathrm{r}$ sector, at least at those sites where the records have been associated with magnetostratigraphic profiles (TonN et al. 1999; BIDEGAIN et al. 2005c). This ungulate is characteristic of the Ensenadan and was found in the B sector of Punta Hermengo. Consequently, the B sector of Punta Hermengo profile can be referred to the chron $\mathrm{C} 1 \mathrm{r}$, probably subchron $\mathrm{C} 1 \mathrm{r} 1 \mathrm{r}(0.90-0.78 \mathrm{M} \mu)$ (Fig. $3 \mathrm{~A}, \mathrm{~B})$.

\subsection{Paleoenvironmental aspects}

Even though the extant mammal species prevailing in Punta Hermengo correspond to the Subtropical Domain, no remains of these taxa have been recorded in any of the sectors in the profile described by TONNI \& FIDALGO (1982), and thus these authors indicate that the deposit would have occurred under arid to semiarid climatic conditions, with predominant presence of Patagonian and Central fauna. These climatic conditions are related to the global changes of the glacial Pleistocene (SHACKLETON 1995) that generated several glacial advances in the Patagonian region (SINGER et al. 2004; RABASSA et al. 2005).

These arid or semiarid conditions favored the expansion of Patagonian and Central faunal elements (i.e., Tolypeutes matacus, Dolichotis patagonum, Zaedyus pichiy, Microcavia australis, Lyncodon patagonicus, Lestodelphys halli); $C$. vellerosus belongs to the latter. In this context, its current disjunct distribution may be interpreted as the result of warm and fundamentally humid recent and extant interglacial conditions that have led to the relictic presence of the species in non-climaxic areas and, following CARLINI \& VizCaíno (1987) and GLAZ \& CARLINI (1999), the edaphic characteristics (well-drained sandy sediments of Bahía de Samborombón).

\section{Acknowledgements}

The authors wish to thank ALVARO MonEs for his help during bibliographical research, MARCELO S. Villagra for his help in the abstract translation and the 
reviewers J. Gustavo Scillato-Yané and Jim Loughry for their significant suggestions. This work was partially funded by the grants PICT-R 074, PICT 07-08395, PEI 6433 and PIP 2731, and financial support of Universidad Nacional de La Plata and Comisión de Investigaciones Científicas, Buenos Aires Province.

\section{References}

Ameghino, F. (1889): Contribución al conocimiento de los mamíferos fósiles de la República Argentina. - Acad. Nac. Cien., 6: 1-1027.

Bidegain, J. C., Evans, M. E. \& Van Velzen, A. J. (2005a): A magnetoclimatological investigation of Pampean loess, Argentina. - Geophys. J. Int., 160: 55-62.

Bidegain, J. C., Rico, Y. \& Sives, F. (2005b): Magnetoclimatología en secuencias de loess y paleosuelos del partido de La Plata, Buenos Aires, Argentina. - Actas del XV Congreso Geológico Argentino, Artículo: 143-150.

Bidegain, J. C., Soibelzon, E., Prevosti, F. J., Rico, Y., Verzi, D. H. \& Tonni, E. P. (2005c): Magnetoestratigrafía y bioestratigrafia de las barrancas costeras de Necochea (provincia de Buenos Aires, Argentina). - Actas del XV Congreso Geológico Argentino, Artículo: 239-246.

Bobe Quinteros, R., Behrensmeyer, A. K. \& Carrasco OrmazÁbal, G. (2004): Paleoclima y evolución faunísta en el Plio-Pleistoceno de Africa y América del Sur. - Ameghiniana, 41: 641-649.

Carlini, A. A. \& Scillato-Yané, G. J. (1999): Evolution of Quaternary Xenarthrans (Mammalia) of Argentina. - In: Rabassa, J. \& Salemme, M. C. (Eds.): Quaternary of South America and Antartic Peninsula, 10: 149-176; Rotterdam.

CARLINI, A. A. \& Vizcaíno, S. F. (1987): A new record of the armadillo Chaetophractus vellerosus (Gray, 1865) (Mammalia, Dasypodidae) in the Buenos Aires Province of Argentine: possible causes for the disjunct distribution. - Studies on Neotropical Fauna and Environment, 22: 53-56.

Cione, A. L. \& Tonni, E. P. (1999): Biostratigraphy and chronological scale of uppermost Cenozoic in the Pampean area, Argentina. - In: RABASSA, J. \& SAlemme, M. C. (Eds.): Quaternary of South America and Antarctic Peninsula, 11: 23-52; Rotterdam.

- (2005): Bioestratigrafia basada en mamíferos del Cenozoico superior de la provincia de Buenos Aires, Argentina. - In: DE BARrio, R. E., ETCHEVERry, R. O., Caballé, M. F. \& Llambías, E. (Eds.): Relatorio del XVI Congreso Geológico Argentino, p. 183-200; La Plata.

Cione, A. L., Tonni, E. P., Bond, M., Carlini, A. A., Pardiñas, U. F. J., ScillatoYANÉ, G. J., Verzi, D. H. \& Vucetich, M. G. (1999): Occurrence charts of Pleistocene mammals in the Pampean area, eastern Argentina. - In: RABASSA, J. \& SAlEmme, M. C. (Eds.): Quaternary of South America and Antartic Peninsula, 12: 53-59; Rotterdam.

DEMENOCAL, P. B. (2004): African climate change and faunal evolution during the Pliocene-Pleistocene. - Earth Planet. Sci. Lett., 220: 3-24.

Desmarest, A. G. (1804): Tableau méthodique des mammifères. - Nouveau dictionnaire d'histoire naturelle, 24: 28; Paris. 
FERNÁNDEZ, M. (1931): Sobre la anatomía microscópica y embriología de la coraza de Dasypus villosus Desm. - Actas de la Academia Nacional de Ciencias de la República Argentina, 10: 121; Buenos Aires.

Glaz, D. \& CARlini, A. A. (1999): Estimación preliminar del Home Range y Area Máxima de Actividad en Chaetophractus vellerosus (Mammalia, Dasypodidae). XIV Jornadas Argentinas de Mastozoología, Resúmenes: 18; Salta.

GoYa, J., Placci, C., Arturi, M. \& Brown, A. (1992): Distribución y características estructurales de los Talares de la reserva de biosfera "Parque Costero del Sur". Rev. Fac. Agronomía, Univ. Nac. La Plata, 68: 53-64.

GraY, J. E. (1865): Revision of the genera and species of entomophagous Edentata, founded on the examination of the specimens in the British Museum. - Proc. Sci. Meet. Zool. Soc. London, 359-386.

Helmens, K. F., Barendregt, R. W., Enkin, R. J., Baker, J. \& Andriessen, P. A. M. (1997): Magnetic Polarity and Fission-Track Chronology of a Late PliocenePleistocene Paleoclimatic Proxy Record in the Tropical Andes. - Quat. Res., 48: $15-28$.

Kraglievich, L. (1952): El perfil geológico de Chapadmalal y Miramar, Provincia de Buenos Aires. - Revista del Museo Municipal de Ciencias Naturales y Tradicional de Mar del Plata, 1: 8-37; Mar del Plata.

MacFAdDEN, B. J. (2000): Middle Pleistocene Climate Change Recorded in Fossil Mammal Teeth from Tarija, Bolivia, and Upper Limit of the Ensenadan LandMammal Age. - Quat. Res., 54: 121-131.

Murriello, S., Arturi, M. \& Brown, A. (1993): Fenología de las especies arboreas de los talares del este de la provincia de Buenos Aires. - Ecología Austral., 3: 25-31.

Nabel, P. E., Cione, A. \& Tonni, E. P. (2000): Environmental changes in the Pampean area of Argentina at the Matuyama-Brunhes (Clr-Cln) Chrons boundary. - Palaeogeogr., Palaeoclimatol., Palaeoecol., 162: 403-412.

Nowak, R. M. (1999): Order Xenarthra. - Walker's Mammals of the world, p. 149-168.

Petit, J. R., Jouzel, J., Raynaud, D., Barkov, N. I., Barnola, J. M., Basile, I., Bender, M., Chappellaz, J., Davis, M., Delaygue, G., Delmotte, M., Kotlaykov, V. M., Legrand, M., Lipenkov, V. Y., Lorius, C., Pepin, L., Ritz, C., SAltzMan, E. \& Stievenard, M. (1999): Climate and atmospheric history of the past 420,000 years from the Vostok ice core, Antarctica. - Nature, 399: 429-436.

PRIETO, A. R. (2000): Vegetational history of the Late glacial-Holocene transition in the grasslands of eastern Argentina. - Palaeogeogr., Palaeoclimatol., Palaeoecol., 157: $167-188$.

Quattrocchio, M. E. \& Borromei, A. M. (1998): Paleovegetational and paleoclimatic changes during the late Quaternary in southwestern Buenos Aires Province and southern Tierra del Fuego (Argentina). - Palynology, 22: 67-82.

Rabassa, J., Coronato, A. M. \& Salemme, M. (2005): Chronology of the Late Cenozoic Patagonian glaciations and their correlation with biostratigraphic units of the Pampean region (Argentina). - J. S. Amer. Earth Sci., 20: 81-103. 
ScIllato-Yané, G. I. (1982): Los Dasypodidae (Mammalia, Edentata) del Plioceno y Pleistoceno de Argentina. - Tesis Doctoral N $N^{\circ} 406$ Facultad de Ciencias Naturales y Museo, Universidad Nacional de La Plata.

Shackleton, N. J. (1995): New data on the evolution of Pliocene climatic variability. - Paleoclimate and Evolution, With Emphasis on Human Origins, p. 242-248.

Singer, B. S., Laurie, L. L., Rabassa, J. \& Guillou, H. (2005): Glaciaciones, cronología ${ }^{40} \mathrm{Ar} /{ }^{39} \mathrm{Ar}$ y paleomagnetismo del Plioceno tardío y Pleistoceno temprano, Cerro del Fraile, provincia de Santa Cruz, Argentina. - Actas del XV Congreso Geológico Argentino, Artículo: 199-206.

Singer, B. S., Robert, P. JR. \& Guillou, H. (2004): 40Ar/39Ar and K-Ar chronology of Pleistocene glaciations in Patagonia. - Bull. Geol. Soc. Amer., 116: 434-450.

Tonni, E. P. \& Cione, A. L. (1997): Did the Argentine Pampean Ecosystem Exist in the Pleistocene? - Current Research in the Pleistocene, 14: 131-133.

Tonni, E. P., Cione, A. L. \& Figrni, A. J. (1999): Predominance of arid climates indicated by mammals in the pampas of Argentina during the Late Pleistocene and Holocene. - Palaeogeogr., Palaeoclimatol., Palaeoecol., 147: 257-281.

TonNi, E. P. \& Fidalgo, F. (1982): Geología y Paleontología de los sedimentos del Pleistoceno en el área de Punta Hermengo (Miramar, Prov. de Buenos Aires, Rep. Argentina): Apectos Paleoclimáticos. - Ameghiniana, 19: 79-108.

Tonni, E. P., Nabel, P., Cione, A. L., Etchibury, M., Tófalo, R., Scillato-Yané, G. J., SAn Cristóbal, J., CARlini, A. A. \& VArgas, D. (1999): The Ensenada and Buenos Aires Formation (Pleistocene) in a quarry near La Plata, Argentina. J. S. Amer. Earth Sci., 12: 273-291.

Tonni, E. P., Pardiñas, U. F. J., Verzi, D. H., Noriega, J. I. \& Scaglia, O. (1998): Microvertebrados pleistocénicos del Sudeste de la provincia de Buenos Aires (Argentina): Bioestratigrafía y Paleoambientes. - V Jornadas Geológicas y Geofísicas, Resúmenes: 73-83; Mar del Plata.

Verzi, D. H., Deschamps, C. M. \& Tonni, E. P. (2004): Biostratigraphic and palaeoclimatic meaning of the Middle Pleistocene South American rodent Ctenomys kraglievichi (Caviomorpha, Octodontidae). - Palaeogeogr., Palaeoclimatol., Palaeoecol., 212: 315-329.

Verzi, D. H., Tonni, E. P., Scaglia, O. A. \& San Cristóbal, J. (2002): The fossil record of the desert-adapted South American rodent Tympanoctomys (Rodentia, Octodontidae). Paleoenvironmental and biogeographic significance. - Palaeogeogr., Palaeoclimatol., Palaeoecol., 179: 149-158.

VizCaíno, S. F. \& Bargo, M. S. (1993): Los Armadillos (Mammalia, Dasypodidae) de La Toma (Partido de Coronel Pringles) y otros sitios arqueológicos de la Provincia de Buenos Aires. Consideraciones Paleoambientales. - Ameghiniana, 30: $435-443$.

Wetzel, R. M. (1982): Systematics, distribution, ecology and conservation of South American Edentates. - Special Publication Pymatuning Lab. of Ecology, 6: 345-375. 
Zachos, J., Pagani, H., Sloan, L., Thomas, E. \& Billups, K. (2001): Trends, rhythms, and aberrations in global climate $65 \mathrm{Ma}$ to present. - Science, 292: 686-693.

Manuscript received: April 7th, 2006.

Revised version accepted by the Stuttgart editor: June 20th, 2006.

\section{Addresses of the authors:}

Esteban Soibelzon*, A. A. Carlini*-**, E. P. Tonni*, L. H. Soibelzon*, *: Dto. Co. Paleontología de Vertebrados, Museo de La Plata, Fac. de Cs. Naturales y Museo, UNLP. Paseo del Bosque s/n, 1900 La Plata. Argentina. **: Cátedra de Anatomía Comparada, Fac. de Cs. Naturales y Museo, UNLP; E-mails: esoibelzon@fcnym.unlp.edu.ar, acarlini@fcnym.unlp.edu.ar, eptonni@fcnym.unlp.edu.ar, 1soibelzon@fcnym.unlp.edu.ar 